\title{
Digital Public Services
}

\subsection{InTRODUCTION}

Governments play a key role in our society by providing citizens and businesses with access to a range of essential public services. As such, there is a constant demand for ways to improve transparency, responsiveness and efficiency in the delivery of these services. The adoption and use of digital technologies provides a number of obvious benefits in this regard and the digitalisation of public services has been a constant item on the agenda of policymakers for over a decade.

The potential benefits generated by the adoption of digital public services have become even more visible during the Covid-19 pandemic when the public were forced to move much of their daily activities online due to restrictions put in place to contain the spread of the virus (European Commission, 2020). In this context, any service that was not online was not accessible, so public organisations were forced to accelerate the adoption of digital technologies and to find more innovative uses of existing e-Government solutions to manage the crisis (United Nations, 2020).

The remainder of this chapter defines digital public services and discusses the benefits and the existing challenges for the implementation of these services in the rural context. Three main types of public services, namely e-Government, e-Health and open data, are then discussed together with extant attempts to measure their adoption and use.

(C) The Author(s) 2022 


\subsection{What Do We Mean by Digital Public Services?}

Digital public services, often termed e-Government, refer to public services provided using digital technologies wherein the interaction with a public sector organisation is mediated by an IT system (Jansen \& Ølnes, 2016; Lindgren \& Jansson, 2013; Lindgren et al., 2019). While most of the focus around e-Government is on public service delivery, the concept of digital public services is broader than that, as it encompasses all interactions between citizens and public bodies.

Lindgren et al. (2019) discuss the impact of the digitalisation of public services from the perspective of the public encounter as conceptualised by Goodsell (1981). The public encounter is defined as "the interaction of citizen and official as they communicate to conduct business" (Goodsell, 1981, p. 4) and is characterised by four general aspects: (1) nature and purpose of the encounter, (2) the actors involved, (3) the communication form and setting in which the encounter occurs, and (4) the encounter's initiation, duration and scope. The shift from traditional to digital public services has an impact on all these characteristics of the encounter, as summarised in Table 3.1.

With regard to the nature of the encounter, digital technologies have mostly been adopted to mimic traditional paper-based processes (Heeks, 2006) and act as mediators of public services. This means that the technology is typically used to provide citizens with access to a public service but the technology does not deliver the service itself (Lindgren \& Jansson, 2013). From the perspectives of communication and ease of access, this generates clear efficiencies. However most services still rely on human

Table 3.1 Summary of changes to the public encounter (adapted from Lindgren et al., 2019)

\begin{tabular}{|c|c|}
\hline Characteristic & $\operatorname{Impact}(s)$ \\
\hline Nature and purpose & $\begin{array}{l}\text { Digitalisation facilitates the exchange of information and citizen } \\
\text { self-service. }\end{array}$ \\
\hline Actors involved & $\begin{array}{l}\text { Digitalisation changes the role of actors involved and } \\
\text { introduces new actors related to the technology. }\end{array}$ \\
\hline $\begin{array}{l}\text { Communication form } \\
\text { and setting }\end{array}$ & $\begin{array}{l}\text { Digitalisation provides additional communication channels. } \\
\text { The setting changes from an official setting to (potentially) } \\
\text { anywhere. }\end{array}$ \\
\hline $\begin{array}{l}\text { Initiation, duration and } \\
\text { scope }\end{array}$ & $\begin{array}{l}\text { Digitalisation enables } 24 / 7 \text { access to public services and } \\
\text { changes citizens' expectations of government response time. }\end{array}$ \\
\hline
\end{tabular}


intervention, so the impact on the average lead time is marginal. Recent advancements associated with machine learning and artificial intelligence offer clear opportunities for seamless automated service provisioning and associated benefits in terms of shorter lead time and higher transparency (Wihlborg et al., 2016; Matheus et al., 2020). Automation may also introduce new risks. These are mostly related to the potential bias in the algorithms that could exclude specific groups of citizens from accessing a service (Wihlborg et al., 2016), and the introduction of new actors, technology providers, who are typically private institutions and multi-tenant in nature. As such, they are responsible for securing and maintaining multiple different service delivery platforms - thus introducing additional risks (Janssen \& Klievink, 2009; Lindgren et al., 2019).

The adoption of digital technologies may also change how the provisioning of public services is initiated. In a traditional setting, one of the actors involved would initiate the encounter, but now the use of algorithms and predictive analytics may lead to proactive service provisioning based on a constant incoming data flow (Scholta et al., 2019). In this context, the definition of a start and an end point becomes blurry and potential concerns regarding government surveillance may arise. Furthermore, digital public services introduce a major change compared to the traditional public encounter with regard to where the service is actually accessed or provisioned. The fact that citizens can access digital services from a digital device instead of a physical public office provides obvious benefits but it is still unclear whether there may be negative outcomes associated with detaching public services from the traditional places of government (Pollitt, 2012).

Despite some concerns, some of which are briefly mentioned above, the increasing adoption of digital public services promises to deliver enormous benefits for both public organisations and citizens. This promise however is based on two major assumptions. First that citizens will have equal and widespread access to the Internet, and second that they will possess the skills required for interacting with public bodies online (Pors, 2015; Williams et al., 2016; Almeida et al., 2019; Lindgren et al., 2019). Previous studies suggest that e-Government initiatives can be hindered by the digital divide and even contribute to it in some cases (Ebbers et al., 2016). Bélanger and Carter (2009), for example, demonstrate that demographic factors such as income, education and age have a significant impact on the intentions of citizens to use e-Government services. This is mostly related to the so-called "access divide" where specific cohorts of the 
population have access to the Internet and digital services while others do not. While enabling widespread access to connectivity has traditionally been one of the main objectives of public and private initiatives (Salemink et al., 2017), research suggests that the physical access divide has evolved into a skills divide where citizens' ability to use the internet and online search experience represents a key determinant of adoption and use of online public services (Bélanger \& Carter, 2009; Van Deursen \& Van Dijk, 2011). This is particularly important in rural areas as they are typically characterised by lower than average levels of education and skills (Salemink et al., 2017) and may therefore be left behind when governments pursue greater digital provision of public services (Van Deursen \& Van Dijk, 2011; Ebbers et al., 2016).

\subsection{E-GOVERNMENT}

A number of frameworks have been proposed to measure the maturity and sophistication of e-Government solutions. An early framework was that proposed by Layne and Lee (2001) comprising four main stages:

1. Cataloguing: government information is made available on a publicly accessible website.

2. Transaction: as the level of sophistication of both government and users evolves, digital channels become another way for citizens to access public services and seek to utilise them. Citizens begin to demand that government requirements can be fulfilled online.

3. Vertical integration: at this stage, the focus is on transforming government services instead of just digitising existing processes.

4. Horizontal integration: databases across different government departments or functional areas communicate with each other so that information obtained by one department propagates to other functions.

One of the most referenced follow-up frameworks to Layne and Lee (2001) is that adopted by the United Nations Global e-Government Survey (United Nations, 2003). First presented in the early 2000s, like Layne and Lee's (2001), the UN model comprises four stages:

1. Emerging: this stage is somewhat comparable to Cataloguing in Layne and Lee (2001) as the government simply provides information to citizens via digital means. 
2. Enhanced: basic one-way or two-way communication between citizens and government is introduced at this stage.

3. Transactional: services can be requested and delivered via digital means through forms.

4. Connected: governments engage in cross-agency integrative services using multiple technologies and platforms.

As Heeks (2015) points out, maturity models are a product of their time and are often context-related. In fact, these initial frameworks are mostly focused on technology adoption reflecting the early stage of development of Internet technologies at the time and are not particularly concerned about the real impact, use, and usefulness of e-Government solutions (Kawashita et al., 2020). Similarly, these initial models are quite rigid and are not able to take into account changing requirements, conditions and developments related to contextual or technological changes (Bertot et al., 2016). A number of frameworks have tried to overcome such limitations by using a variable number of maturity levels which makes a direct comparison quite difficult. Table 3.2 provides a summary and comparison of these models.

The EU eGovernment Framework Benchmark (European Commission, 2020) departs from the concept of maturity. Rather, it "is built on the foundation of the EU policy priority areas in the field of e-Government" (van der Linden et al., 2020, p. 8)-user empowerment, preconditions and the digital single market - and translates them into four key dimensions:

1. User centricity: the extent to which information and services are available, supported and compatible with mobile devices.

2. Transparency: the extent to which service processes are transparent and co-designed with users, and users can access and manage their personal data.

3. Key enablers: the extent to which main IT enablers such as, electronic IDs, eDocuments and security are available to users. The presence of these enablers can be used to assess the technical pre-conditions for the efficient and effective use of online services.

4. Cross-border services: the extent to which online information and services are integrated with eIDs and eDocuments for users from other European countries. 


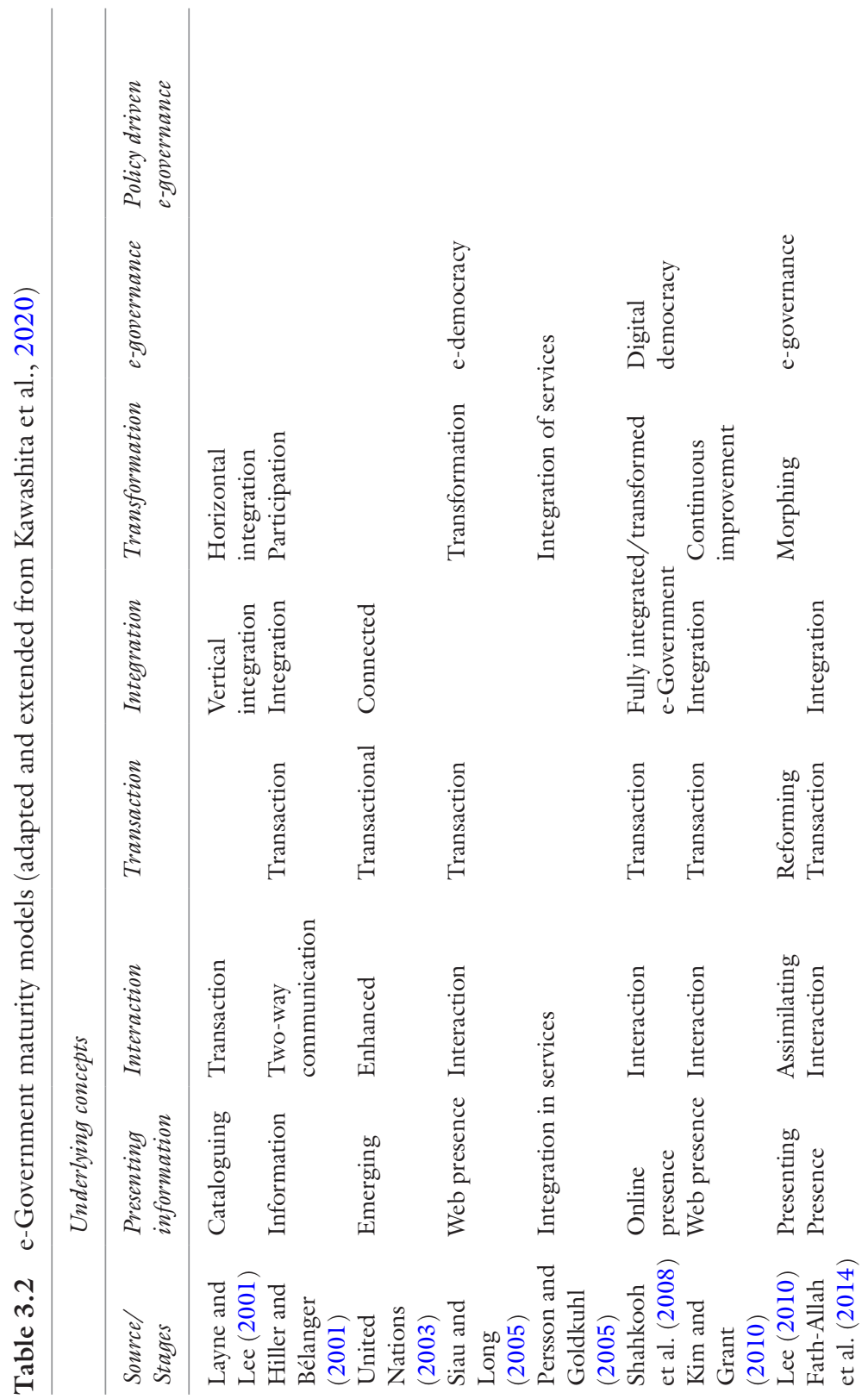


3 DIGITAL PUBLIC SERVICES $\mathbf{5 5}$

菊

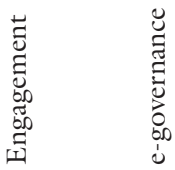

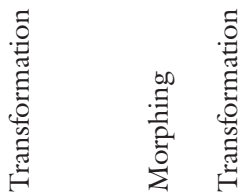

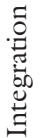

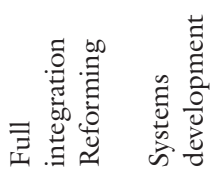

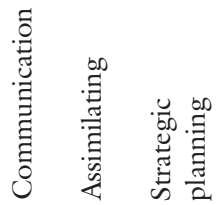

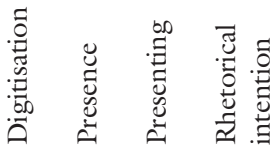

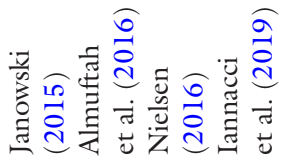


Furthermore, most indicators included in the EU eGovernment Framework Benchmark are collected by "mystery shoppers" who are "trained and briefed to observe, experience, and measure a service process by acting as a prospective user" (van der Linden et al., 2020, p. 15). As such, the EU framework represents a shift from supply-side maturity (government) to demand-side experience (citizens).

This user-centricity is also reflected in the UN e-participation index which emphasises citizen participation as the cornerstone of socially inclusive governance. As such, it focuses on the provision of information by governments to citizens ("e-information sharing"), interaction with stakeholders ("e-consultation"), and engagement in decision-making processes ("e-decision making") (UN, 2021). Links to additional information on selected indicators are provided in the Useful Links section at the end of the book.

\subsection{E-HeALth}

The e-Government maturity frameworks presented in the previous section consider digital public services in their entirety, as if they represent an homogenous group of services delivered by public organisations. In reality though, public services are not all the same and some are more suitable for digital interaction/delivery than others (Lindgren et al., 2019). Among all public services, healthcare is arguably one of the most important for citizens. Unsurprisingly, e-Health has been on the agenda of policy makers for a long time and has been the focus of a number of digitisation initiatives (Domenichiello, 2015).

$\mathrm{e}$-Health can be defined as "the use of Information and Communication Technologies (ICT) across the whole range of healthcare functions" (European Commission, 2004) and comprises a wide range of applications that can benefit citizens, healthcare professionals and organisations, and public authorities by improving medical practices, simplifying the prescription of diagnostic procedures, producing alerts and reminders, and reducing errors (Bodell et al., 2004; Delpierre et al., 2004; Kaushal et al., 2006; Øvretveit et al., 2007). Cowie et al. (2016) summarise these domains as follows:

- Telemedicine and telecare: disease management services, remote patient monitoring, teleconsultations, and homecare. 
- Clinical information systems: electronic health and medical records (EHR) and Computerised Decision Support Systems (CDSSs).

- Integrated regional and national information networks and associated electronic referrals and prescriptions (e-prescribing).

- Disease registries and other non-clinical systems: systems used for education, public health, patient/disease-related behaviour, and healthcare management.

- "Mobile" health (m-health): medical and public health practice supported by mobile technologies delivering health information, screening patients, monitoring physiological signs, providing direct care and patient education.

- 'Personalised' health ( $\mathrm{p}$-health): wearable or implantable micro and nano-technologies with sensors and/or therapy delivery devices to help facilitate health and social care decision making and delivery.

- Big Data: large-scale integration and analysis of heterogeneous data sources, usually of high volume, velocity, and variety, ideally linked at the individual person level to provide a more holistic view of a patient/individual and shed light on social and environmental factors that may influence health.

Even before the Covid-19 pandemic, healthcare systems were already facing significant pressure due to increasing demand and costs, inconsistent quality of care, and inefficient, poorly coordinated processes. As the population in developed countries becomes older, questions have been raised regarding the sustainability of traditional healthcare systems. In the European Union, for example, public health expenditure is expected to represent $8.5 \%$ of GDP by 2060 , a $16 \%$ percent increase compared to 2010 (European Commission, 2012b).

More pervasive use of ICT in healthcare has been proposed as a way to overcome these challenges (WHO, 2016). At a macro level, studies suggest that e-Health solutions can result in significant improvements in terms of system productivity, ease of access, and quality of service (Hackett et al., 2019). Successful implementations seem to support this argument. Canada, for example, launched its first eHealth plan in 2001 (Canada Health Infoway, 2021); current estimated savings amount to approximately CAD 119-150 million per annum with a concurrent increase in service quality (Hackett et al., 2019). In an attempt to achieve similar results, the European Commission issued a first eHealth action plan in 2004, followed by a revised version issued in 2012 (European 
Commission, 2012a). The main objective of these plans was to increase the adoption of e-Health across different countries but this has proved to be challenging mostly due to lack of awareness of e-Health services, interoperability issues, legal barriers, and high start-up costs (European Commission, 2012a).

General practitioners (GPs) play a central role in facilitating access to and delivery of care as they represent the main point of contact between the healthcare system and citizens, particularly in rural areas (Macinko et al., 2003; Atun, 2004). As such, they are in a position to gather important information which would constitute the basis of an IT-enabled integrated healthcare system (European Commission, 2013). For this reason, the EU mostly focuses on the adoption of e-Health services such as electronic prescriptions (e-prescribing) and data exchanges by GPs when it comes to measuring the digitalisation of healthcare across different countries. However, other actors like pharmacies and specialised health professionals (e.g. physiotherapists, dentists, psychiatrists etc.) may also play a critical role in fostering the adoption of eHealth services within communities (Gregorio et al., 2013; Vorrink et al., 2017; Baines et al., 2018).

Digital Economy and Skills Unit $(2018,2019)$ represent one of the first attempts to include an explicit measure of e-Health adoption in the context of digital public services. However, the framework only includes three indicators-i.e. e-prescription, online consultations, and use of electronic medical data exchange - and results are only presented at a country level so it does not have the necessary level of granularity to assess adoption across different regions or in rural areas. This may ultimately be due to the difficulty of collecting timely data, as the exclusion of e-Health indicators from Digital Economy and Skills Unit (2020) seems to suggest.

\subsection{Open Data}

Another aspect of digital public services that is often not considered explicitly is the availability of open government data (OGD). This involves making public sector information (PSI) freely available in open formats and ways that enable public access and facilitate exploitation (Kalampokis et al., 2011). The main benefits of open data are summarised in Table 3.3 It is important to note that open data on its own has little intrinsic value, as value is only created by its use (Janssen et al., 2012).

PSI is a strategic resource that can generate benefits for a number of actors (Ubaldi, 2013) including: 
Table 3.3 Overview of benefits of open data (Janssen et al., 2012)

\begin{tabular}{|c|c|}
\hline Category & Benefits \\
\hline $\begin{array}{l}\text { Political and } \\
\text { social }\end{array}$ & $\begin{array}{l}\text { - More transparency; } \\
\text { - } \text { Democratic accountability; } \\
\text { - } \text { Core participation and self-empowerment of citizens (users); } \\
\text { - Public engagement; } \\
\text { - Scrutinisation of data; } \\
\text { - Equal access to data; } \\
\text { - } \text { Imew governmental services for citizens; } \\
\text { - Improvement of citizen services; } \\
\text { - Improvement of citizen satisfaction; } \\
\text { - More visibility for the data provider; } \\
\text { - Stimulation of knowledge developments; } \\
\text { - Neation of new insights in the public sector; }\end{array}$ \\
\hline Economic & $\begin{array}{l}\text { Economic growth and stimulation of competitiveness; } \\
\text { - Stimulation of innovation; } \\
\text { - Contribution toward the improvement of processes, products, } \\
\text { and/or services; } \\
\text { - Development of new products and services; } \\
\text { - } \text { the of the wisdom of the crowds: Tapping into the intelligence of } \\
\text { - Creation of a new sector adding value to the economy; } \\
\text { - Availability of information for investors and companies. }\end{array}$ \\
\hline $\begin{array}{l}\text { Operational and } \\
\text { technical }\end{array}$ & $\begin{array}{l}\text { - The ability to reuse data/not having to collect the same data again } \\
\text { and counteracting unnecessary duplication and associated costs } \\
\text { (also by other public institutions); } \\
\text { - Optimisation of administrative processes; } \\
\text { - Improvement of public policies; } \\
\text { - Access to external problem-solving capacity; } \\
\text { - Fair decision-making by enabling comparison; } \\
\text { - Easier access to data and discovery of data; } \\
\text { - Creation of new data based on combining data; } \\
\text { - External quality checks of data (validation); } \\
\text { - The ability to merge, integrate, and mesh public and private data. }\end{array}$ \\
\hline
\end{tabular}

- Governments: open data provides the scope for faster decisionmaking, better resource allocation and efficient, and effective delivery of more personalised public services. 
- Citizens: open data enables public participation and social engagement which may ultimately lead to service co-development.

- Civil society: civil society initiatives that leverage open data may have a wide range of objectives but they generally tend to focus on the vulnerable segments of the population.

- Economic actors: by making more information available, open data can stimulate a competitive marketplace for both public and private sector services. Competition may result in a higher innovation rate and benefits for the overall economy.

The total direct economic value of PSI is expected to increase from a baseline of $€ 52$ billion in 2018 for the EU28 to $€ 194$ billion in 2030 (Barbero et al., 2018) and a similar trend can be expected in other economies. There are a number of initiatives that track open government data initiatives worldwide such as the Global Open Data Index ${ }^{1}$ and the OECD OURdata Index. ${ }^{2}$ However, these frameworks present information at a country level, providing little room for identifying more local initiatives that take place in rural areas. Walker et al. (2020) clearly show that rural open data has a massive economic potential but it is often overlooked by government policies due their focus on smart cities and urban areas.

\subsection{Measuring Digital Public Services}

As noted earlier in Sect. 3.3, there is a wide range of frameworks for measuring e-Government and the use of digital technologies by the public services. The recent G20 Digital Economy Task Force roadmap for measuring the digital economy specifically includes the government as a producer and consumer of economic activity reliant on or enhanced by the use of digital inputs (G20 DETF, 2020). Notwithstanding this, the inclusion of specific public service indicators in international frameworks and composite indices is limited (see Table 3.4).

\footnotetext{
${ }^{1}$ https://index.okfn.org

${ }^{2}$ https://www.oecd.org/gov/digital-government/open-government-data.htm
} 
Table 3.4 Selected international e-Government measurement frameworks and composite indices

\begin{tabular}{|c|c|c|}
\hline Framework & Description & Source \\
\hline $\begin{array}{l}\text { Digital Economy \& } \\
\text { Society Index } \\
\text { (DESI) }\end{array}$ & $\begin{array}{l}\text { Includes a specific eGovernment dimension } \\
\text { that measures: } \\
\text { 1. e-Government users } \\
\text { 2. Pre-filled forms } \\
\text { 3. Online service completion for major } \\
\text { life events } \\
\text { 4. Digital public services for businesses }\end{array}$ & $\begin{array}{l}\text { Digital Economy } \\
\text { and Skills Unit } \\
(2018,2020,2021)\end{array}$ \\
\hline $\begin{array}{l}\text { Digital planet- } \\
\text { digital evolution } \\
\text { index }\end{array}$ & $\begin{array}{l}\text { In the Institutional Environment theme, } \\
\text { government uptake and use of ICT is } \\
\text { measured. }\end{array}$ & $\begin{array}{l}\text { Chakravorti et al. } \\
(2015)\end{array}$ \\
\hline $\begin{array}{l}\text { G20 toolkit for } \\
\text { measuring the } \\
\text { digital economy }\end{array}$ & $\begin{array}{l}\text { Includes one indicator in the empowering } \\
\text { society theme regarding individuals using } \\
\text { the internet to interact with public } \\
\text { authorities. }\end{array}$ & $\begin{array}{l}\text { G20 Digital } \\
\text { Economy Task Force } \\
(2018)\end{array}$ \\
\hline $\begin{array}{l}\text { Partnership on } \\
\text { measuring ICT for } \\
\text { development }\end{array}$ & $\begin{array}{l}\text { Includes } 7 \text { indicators in an ICT in } \\
\text { government theme covering: } \\
\text { - Employment }(2) \\
\text { - Government internet and network } \\
\text { access }(3) \\
\text { - Web presence }(1) \\
\text { - Selected internet-based online services } \\
\text { available to citizens by level of } \\
\text { sophistication of service }(1)\end{array}$ & ITU (2016) \\
\hline
\end{tabular}

Where public services are included in international frameworks and composite indices, they are limited to three main themes-access, employment, and use. It is worth noting that access in this context focuses on the access by the public as opposed to government itself (Table 3.5).

E-health is rarely included as a discrete segment in international frameworks and composite indices on the digital economy or digital society. Where it is included, it is typically included in the context of measuring individual or household access and use of the Internet. For example, the Partnership on Measuring ICT for Development utilizes data on individuals and households using the Internet to seek health information or make an appointment with a medical practitioner (ITU, 2016). In addition to similar indicators on usage, DESI has previously reported on the availability of e-prescriptions and online medical consultation (DESU, 2018). National data on individual and household use of the Internet for health purposes is available through a variety of sources including Eurobarometer, Eurostat and the ITU. 
Table 3.5 Themes measured in international digital society and digital economy measurement frameworks and composite indices and indicative benchmark data sources

\begin{tabular}{lll}
\hline Themes & Description & $\begin{array}{l}\text { Selected international benchmark } \\
\text { data sources }\end{array}$ \\
\hline Access & $\begin{array}{l}\text { Availability and access to public services } \\
\text { online within a country and abroad. }\end{array}$ & $\begin{array}{l}\text { EU eGovernment Benchmarking } \\
\text { Report (European Commission, } \\
\text { 2020); Eurostat; ITU }\end{array}$ \\
Employment & $\begin{array}{l}\text { Employment in the government roles } \\
\text { using ICT. }\end{array}$ & $\begin{array}{l}\text { Eurostat, ILO labour force } \\
\text { surveys; OECD structural } \\
\text { analysis (STAN) database; ITU }\end{array}$ \\
Use & $\begin{array}{l}\text { Availability, intensity and patterns of } \\
\text { digital technology use by citizens and } \\
\text { businesses to interact with the }\end{array}$ & $\begin{array}{l}\text { EU eGovernment Benchmarking } \\
\text { Report (European Commission, }\end{array}$ \\
& government. & \\
\hline
\end{tabular}

Other than DESI, open data is not included in any other major international framework on the digital society or digital economy. DESI measures the maturity of open data in a given country based on:

- Open data readiness: the extent to which countries have an open data policy in place, licensing norms, and the extent of national coordination regarding guidelines and setting common approaches.

- Portal maturity: the portal's usability regarding the availability of functionalities, the overall re-usability of data such as machine readability and accessibility of datasets, as well as the spread of data across domains.

Data on open data maturity is available from the European Data Portal. ${ }^{3}$

\subsection{Conclusion}

Public services underpin economic activity and are essential for the functioning of society. Despite this, public service delivery has historically been inefficient and, for many, lacks sufficient accessibility-particularly for those in rural and remote areas. The adoption and use of digital

\footnotetext{
${ }^{3}$ https://data.europa.eu/en/impact-studies/open-data-maturity
} 
technologies can generate substantial benefits in this context by making services more accessible, convenient and efficient. A large number of initiatives have been put in place by national governments to provide public services via digital channels. In line with these initiatives, a similarly large number of maturity frameworks to classify these initiatives have been proposed. Unfortunately, many of these lack commonality or do not address relatively smaller towns and rural communities. As a consequence, very little is known about the adoption and use of digital public services at a rural or municipal government level. It would seem that even for digital public services, an urban-rural digital divide remains.

\section{REFERENCES}

Almeida, V., Filgueiras, F., \& Gaetani, F. (2019). Principles and elements of governance of digital public services. IEEE Internet Computing, 23(6), 48-53.

Almuftah, H., Weerakkody, V., \& Sivarajah, U. (2016). Comparing and contrasting e-government maturity models: A qualitative-meta synthesis. Electronic Government and Electronic Participation: Joint Proceedings of Ongoing Research and Projects of IFIP WG, 8, 69-79.

Atun, R. (2004). What are the advantages and disadvantages of restructuring a health care system to be more focused on primary care services? WHO Regional Office for Europe's Health Evidence Network (HEN).

Baines, D., Gahir, I. K., Hussain, A., Khan, A. J., Schneider, P., Hasan, S. S., \& Babar, Z. U. D. (2018). A scoping review of the quality and the design of evaluations of mobile health, telehealth, smart pump and monitoring technologies performed in a pharmacy-related setting. Frontiers in Pharmacology, 9, 678.

Barbero, M., Bartz, K., Linz, F., Mauritz, S., Wauters, P., Chrzanowski, P., \& Osimo, D. (2018). Study to support the review of directive 2003/98/EC on the re-use of public sector information. Deloitte, Brussels.

Bélanger, F., \& Carter, L. (2009). The impact of the digital divide on e-government use. Communications of the ACM, 52(4), 132-135.

Bertot, J., Estevez, E., \& Janowski, T. (2016). Universal and contextualized public services: Digital public service innovation framework. Government Information Quarterly, 33(2), 211-222.

Bodell, R., Covvey, H. D., \& Fader, C. (2004). Achieving a 'therapeutic dose' of IT. Studies in Health Technology and Informatics, 107(Pt 2), 1348-1351.

Canada Health Infoway. (2021). Our history. https://www.infoway-inforoute. $\mathrm{ca} / \mathrm{en} /$ about-us/our-history

Chakravorti, B., Chaturvedi, R., \& Tunnard, C. (2015). Where the digital economy is moving the fastest. Harvard Business Review. https://hbr.org/2015/ $02 /$ where-the-digital-economy-is-moving-the-fastest 
Cowie, M. R., Bax, J., Bruining, N., Cleland, J. G., Koehler, F., Malik, M., ... Vardas, P. (2016). E-health: A position statement of the European Society of Cardiology. European Heart Journal, 37(1), 63.

Delpierre, C., Cuzin, L., Fillaux, J., Alvare, M., Massip, P., \& Lang, T. (2004). A systematic review of computer-based patient record systems and quality of care: More randomized clinical trials or a broader approach? International Journal for Quality in Health Care, 16(5), 407-416.

Digital Economy and Skills Unit. (2018). Digital Economy and Society Index Report 2018-Digital Public Services. http://ec.europa.eu/newsroom/dae/ document.cfm?doc_id=52244

Digital Economy and Skills Unit. (2019). Digital Economy and Society Index Report 2019-Digital Public Services. https://ec.europa.eu/newsroom/dae/ document.cfm?doc_id=59975

Digital Economy and Skills Unit. (2020). Digital Economy and Society Index (DESI) 2020-Digital Public Services. https://ec.europa.eu/newsroom/dae/ document.cfm?doc_id=67084

Digital Economy and Skills Unit. (2021). The digital economy and society index (DESI) 2020. https://ec.europa.eu/newsroom/dae/document. cfm?doc_id=67086

Domenichiello, M. (2015). State of the art in adoption of e-Health services in Italy in the context of European Union E-Government strategies. Procedia Economics and Finance, 23, 1110-1118.

Ebbers, W. E., Jansen, M. G., \& van Deursen, A. J. (2016). Impact of the digital divide on e-government: Expanding from channel choice to channel usage. Government Information Quarterly, 33(4), 685-692.

European Commission. (2004). e-Health-Making healthcare better for European citizens: An action plan for a European e-Health Area. COM (2004) 356 final. European Commission.

European Commission. (2012a). eHealth action plan 2012-2020: Innovative bealthcare for the 21st century. Brussels.

European Commission. (2012b). The 2012 ageing report: Economic and budgetary projections for the 27 EU member states (2010-2060). Brussels.

European Commission. (2013). Benchmarking deployment of eHealth among general practitioners. Digital Agenda for Europe. Final Report.

European Commission. (2020). eGovernment benchmark 2020: eGovernment that works for the people. https://digital-strategy.ec.europa.eu/en/library/ egovernment-benchmark-2020-egovernment-works-people

Fath-Allah, A., Cheikhi, L., Al-Qutaish, R. E., \& Idri, A. (2014). E-government maturity models: A comparative study. International Journal of Software Engineering \& Applications, 5(3), 71-91.

G20 Digital Economy Task Force (DETF). (2018). G20 toolkit for measuring the digital economy. OECD. https://www.oecd.org/g20/summits/buenosaires /G20-Toolkit-for-measuring-digital-economy.pdf 
G20 Digital Economy Task Force (DETF). (2020). A roadmap toward a common framework for measuring the digital economy. OECD.

Goodsell, C. T. (Ed.). (1981). The public encounter: Where state and citizen meet. Indiana University Press.

Gregorio, J., Ferreira, T. L., Cavaco, A., da Silva, M. M., Lovis, C., \& Lapão, L. V. (2013, June). Community pharmacies and ehealth services: Barriers and opportunities for real primary healthcare integration. In Proceedings of the 26th IEEE international symposium on computer-based medical systems (pp. 393-396). IEEE.

Hackett, C., Brennan, K., Fowler, H. S., \& Leaver, C. (2019). Valuing citizen access to digital health services: Applied value-based outcomes in the Canadian context and tools for modernizing health systems. Journal of Medical Internet Research, 21(6), e12277.

Heeks, R. (2006). Implementing and managing eGovernment: An international text. Sage.

Heeks, R. (2015). A Better e-Government Maturity Model. iGovernment Briefing No. 9. Centre for Development Informatics, University of Manchester.

Hiller, J. S., \& Bélanger, F. (2001). Privacy strategies for electronic government. E-Government, 200, 162-198.

Iannacci, F., Seepma, A. P., De Blok, C., \& Resca, A. (2019). Reappraising maturity models in e-government research: The trajectory-turning point theory. The Journal of Strategic Information Systems, 28(3), 310-329.

ITU. (2016). Core list of ICT indicators. https://www.itu.int/en/ITU-D/ Statistics/Documents/coreindicators/Core-List-of-Indicators_ March2016.pdf

Janowski, T. (2015). Digital government evolution: From transformation to contextualization. Government Information Quarterly, 32(3), 221-236.

Jansen, A., \& Ølnes, S. (2016). The nature of public e-services and their quality dimensions. Government Information Quarterly, 33(4), 647-657.

Janssen, M., \& Klievink, B. (2009). The role of intermediaries in multi-channel service delivery strategies. International Journal of Electronic Government Research (IJEGR), 5(3), 36-46.

Janssen, M., Charalabidis, Y., \& Zuiderwijk, A. (2012). Benefits, adoption barriers and myths of open data and open government. Information Systems Management, 29(4), 258-268.

Kalampokis, E., Hausenblas, M., \& Tarabanis, K. (2011, August). Combining social and government open data for participatory decision-making. In International conference on electronic participation (pp. 36-47). Springer.

Kaushal, R., Jha, A. K., Franz, C., Glaser, J., Shetty, K. D., Jaggi, T., \& Bates, D. W. (2006). Return on investment for a computerized physician order entry system. Journal of the American Medical Informatics Association, 13(3), 261-266. 
Kawashita, I. M. S., Baptista, A. A., \& Soares, D. (2020, April). E-government maturity models: more of the same?. In 2020 Seventh International Conference on eDemocracy \& eGovernment (ICEDEG) (pp. 58-66). IEEE

Kim, D. Y., \& Grant, G. (2010). E-government maturity model using the capability maturity model integration. Journal of Systems and Information Technology, 12(3), 230-244.

Layne, K., \& Lee, J. (2001). Developing fully functional e-government: A four stage model. Government Information Quarterly, 18(2), 122-136.

Lee, J. (2010). 10 year retrospect on stage models of e-government: A qualitative meta-synthesis. Government Information Quarterly, 27(3), 220-230.

Lindgren, I., \& Jansson, G. (2013). Electronic services in the public sector: A conceptual framework. Government Information Quarterly, 30(2), 163-172.

Lindgren, I., Madsen, C. Ø., Hofmann, S., \& Melin, U. (2019). Close encounters of the digital kind: A research agenda for the digitalization of public services. Government Information Quarterly, 36(3), 427-436.

Macinko, J., Starfield, B., \& Shi, L. (2003). The contribution of primary care systems to health outcomes within Organization for Economic Cooperation and Development (OECD) countries. 1970-1998. Health Services Research, 38(3), 831-865.

Matheus, R., Janssen, M., \& Maheshwari, D. (2020). Data science empowering the public: Data-driven dashboards for transparent and accountable decisionmaking in smart cities. Government Information Quarterly, 37(3), 101284.

Nielsen, M. M. (2016, January). The role of governance, cooperation, and eservice use in current egovernment stage models. In 2016 49th Hawaii International Conference on System Sciences (HICSS) (pp. 2850-2860). IEEE.

Øvretveit, J., Scott, T., Rundall, T. G., Shortell, S. M., \& Brommels, M. (2007). Implementation of electronic medical records in hospitals: Two case studies. Health Policy, 84(2-3), 181-190.

Persson, A., \& Goldkuhl, G. (2005, February). Stage-models for public e-servicesinvestigating conceptual foundations. In 2nd Scandinavian workshop on e-government, Copenhagen (pp. 14-15).

Pollitt, C. (2012). New perspectives on public services: Place and technology. Oxford University Press.

Pors, A. S. (2015). Becoming digital-Passages to service in the digitized bureaucracy. Journal of Organizational Ethnography, 4(2), 177-192.

Salemink, K., Strijker, D., \& Bosworth, G. (2017). Rural development in the digital age: A systematic literature review on unequal ICT availability, adoption, and use in rural areas. Journal of Rural Studies, 54, 360-371.

Scholta, H., Mertens, W., Kowalkiewicz, M., \& Becker, J. (2019). From one-stop shop to no-stop shop: An e-government stage model. Government Information Quarterly, 36(1), 11-26. 
Shahkooh, K. A., Saghafi, F., \& Abdollahi, A. (2008, April). A proposed model for e-government maturity. In 2008 3rd International conference on information and communication technologies: From theory to applications (pp. 1-5). IEEE.

Siau, K., \& Long, Y. (2005). Synthesizing e-government stage models-A metasynthesis based on meta-ethnography approach. Industrial Management es Data Systems, 105(4), 443-458.

Ubaldi, B. (2013). Open government data: Towards empirical analysis of open government data initiatives. OECD Working Papers on Public Governance.

United Nations. (2003). UN Global E-government Survey 2003. https://publicadministration.un.org/egovkb/Portals/egovkb/Documents/un/2003Survey/Complete-survey.pdf.

United Nations. (2020). United Nations e-Government Survey 2020. https:// publicadministration.un.org/egovkb/en-us/Reports/UN-E-GovernmentSurvey-2020

United Nations. (2021). E-Participation Index. https://publicadministration. un.org/egovkb/en-us/About/Overview/E-Participation-Index

Van Deursen, A., \& Van Dijk, J. (2011). Internet skills and the digital divide. New Media \& Society, 13(6), 893-911.

van der Linden, N., Enzerink, S., Geilleit, R., Dogger, J., et al. (2020). eGovernment benchmark method paper. European Commission. https://bit.ly/3sNKf2k

Vorrink, S., Huisman, C., Kort, H., Troosters, T., \& Lammers, J. W. (2017). Perceptions of patients with chronic obstructive pulmonary disease and their physiotherapists regarding the use of an eHealth intervention. JMIR Human Factors, 4(3), e20.

Walker, J. C., Thuermer, G., Simperl, E., \& Carr, L. (2020, July). Smart rural: The open data gap. In Data for Policy Conference 2020.

Wihlborg, E., Larsson, H., \& Hedström, K. (2016, January). 'The computer says no!'-A case study on automated decision-making in public authorities. In 2016 49th Hawaii International Conference on System Sciences (HICSS) (pp. 2903-2912). IEEE.

Williams, F., Philip, L., Farrington, J., \& Fairhurst, G. (2016). 'Digital by default' and the 'hard to reach': Exploring solutions to digital exclusion in remote rural areas. Local Economy, 31(7), 757-777.

World Health Organization (WHO). (2016). Global diffusion of eHealth: Making universal health coverage achievable. Report of the ... World Health Organization 2016. 
Open Access This chapter is licensed under the terms of the Creative Commons Attribution 4.0 International License (http://creativecommons.org/licenses/ by $/ 4.0 /$ ), which permits use, sharing, adaptation, distribution and reproduction in any medium or format, as long as you give appropriate credit to the original author(s) and the source, provide a link to the Creative Commons licence and indicate if changes were made.

The images or other third party material in this chapter are included in the chapter's Creative Commons licence, unless indicated otherwise in a credit line to the material. If material is not included in the chapter's Creative Commons licence and your intended use is not permitted by statutory regulation or exceeds the permitted use, you will need to obtain permission directly from the copyright holder. 